\title{
Synthesis of non-magnetic-ion-substituted Ca-based M-type ferrite
}

\author{
M. Shigemura, K. Kakizaki, and K. Kamishima \\ Graduate School of Science and Engineering, Saitama University, 255 Shimo-okubo, Sakura-ku, Saitama, Japan
}

We investigated the synthesis conditions and magnetic properties of non-magnetic-ion-substituted Ca-based hexagonal ferrites, $\mathrm{Ca} 0.8 \mathrm{La} 0.2 \mathrm{Fe} 8.0-2{ }_{x} \mathrm{Mg}_{x} \mathrm{Ti}_{x} \mathrm{O}_{19-\sigma}(x=0.1-3.5)$ and $\mathrm{Ca}_{0.8} \mathrm{La}_{0.2} \mathrm{Fe}_{y-x} \mathrm{Al}_{x} \mathrm{O}_{19-\sigma}(x=1.0-5.0, y=8.0-10)$. We found that Mg-Ti-substituted Ca-based M-type ferrites formed at $x=0.1$ and 0.2 at above $1225^{\circ} \mathrm{C}$. The sample at $x=$ 0.1 showed the crystallographic single phase of M-type ferrite. The minimum Curie temperature of the $\mathrm{Mg}$-Ti-substituted samples was $367^{\circ} \mathrm{C}$. Also, we found that the $\mathrm{Al}$-substituted Ca-based $\mathrm{M}$-type ferrites had the main phase of $\mathrm{M}$-type ferrite in all samples. As the amount of substituted $\mathrm{Al}$ increased, the saturation magnetization and the Curie temperature decreased, and the coercivity increased. As the amount of substituted $\mathrm{Al}$ increased by $\Delta x=1$, the Curie temperature decreased by $\Delta T_{\mathrm{C}}=50-70^{\circ} \mathrm{C}$. Al-substituted samples of $x=1.0$ and 2.0 sintered at $1300^{\circ} \mathrm{C}$ had the single phase of M-type ferrite.

Keywords: hexagonal ferrites, M-type, calcium compound, non-magnetic ions, Mg-Ti, Al

\section{Introduction}

M-type ferrite is a type of hexagonal ferrite. Its chemical formula is expressed as $\mathrm{M}^{2+} \mathrm{Fe}^{3+}{ }_{12} \mathrm{O}_{19}$ $\left(\mathrm{M}^{2+}=\mathrm{Ba}^{2+}, \mathrm{Sr}^{2+}\right)$. The M-type ferrite has high saturation magnetization and high coercivity and is mainly used as a permanent magnet. The Curie temperatures of $\mathrm{BaFe}_{12} \mathrm{O}_{19}$ and $\mathrm{SrFe}_{12} \mathrm{O}_{19}$ are $450^{\circ} \mathrm{C}$ and $460^{\circ} \mathrm{C}$, respectively. ${ }^{1)-4)}$ It is also possible to tune the magnetic properties of the pure M-type ferrites by the substitution of non-magnetic ions such as $\mathrm{Mg}^{2+-} \mathrm{Ti}^{4+}$, $\mathrm{Zn}^{2+-} \mathrm{Ti}^{4+}$, and $\mathrm{Al}^{3+}{ }^{5}{ }^{-10)}$

On the other hand, we had investigated the synthesis conditions of Ca-based M-type ferrite in our previous study. ${ }^{11)}$ In the study, the sintering temperature of the highest magnetization sample was $1250^{\circ} \mathrm{C}$ and the analyzed composition was approximately $\mathrm{Ca}: \mathrm{La}: \mathrm{Fe}=$ $0.8: 0.2: 9.0$. The saturation magnetization of the sample was $68.0 \mathrm{Am}^{2} / \mathrm{kg}$ at room temperature and $104 \mathrm{Am}^{2} / \mathrm{kg}$ at $5 \mathrm{~K}\left(-268^{\circ} \mathrm{C}\right)$. The Curie temperature of this sample was about $400^{\circ} \mathrm{C}$.

In this study, we investigated the synthesis conditions and magnetic properties of non-magnetic-ionsubstituted Ca-based M-type ferrites. The substitution of non-magnetic ions for $\mathrm{Fe}^{3+}$ can decrease the Curie temperature of a ferrite, which gives the opportunity for new application. For instance, Shimizu et al. put forward the non-magnetic-ion-substituted spinel ferrites with relatively low Curie temperatures as the implant material for the magnetic induction hyperthermia therapy. ${ }^{12)-13)}$

We employed $\mathrm{Mg}^{2+-} \mathrm{Ti}^{4+}$ and $\mathrm{Al}^{3+}$ as non-magnetic substituting elements in the Ca-based M-type ferrite. The resources of these elements are rich as well as those of $\mathrm{Ca}$ and $\mathrm{Fe} .{ }^{14)}$ Also, $\mathrm{Ca}, \mathrm{Mg}, \mathrm{Ti}$, and $\mathrm{Al}$ are less toxic than $\mathrm{Ba}$, which is helpful in terms of producing a safer material.

\section{Experimental Procedure}

Samples were prepared by a conventional ceramic method. We used $\mathrm{CaCO}_{3}, \mathrm{La}_{2} \mathrm{O}_{3}, \alpha-\mathrm{Fe}_{2} \mathrm{O}_{3}$, and $(\mathrm{MgO}$, $\mathrm{TiO}_{2}$ ) or $\mathrm{Al}_{2} \mathrm{O}_{3}$ as starting materials. They were mixed in a desired proportion, $\mathrm{Ca}_{0.8} \mathrm{La}_{0.2} \mathrm{Fe}_{8.0-2 x} \mathrm{Mg}_{x} \mathrm{Ti}_{x} \mathrm{O}_{19-\sigma}(x$ $=0.1-3.5)$, or $\mathrm{Ca}_{0.8} \mathrm{La}_{0.2} \mathrm{Fe}_{y^{-} x} \mathrm{Al}_{x} \mathrm{O}_{19-\sigma}(x=1.0-4.0, y=$ 8.0-10). The powder was ball-milled for $24 \mathrm{~h}$. The mixed powder was pressed into a pellet shape and pre-calcined in air at $900^{\circ} \mathrm{C}$. The sintered sample was pulverized in a mortar and then milled into fine powder with a planetary ball mill (Fritsch, P-7 Premium line with 1 $\mathrm{mm} \phi$ zirconia balls and a $45 \mathrm{ml}$ zirconia container) for $10 \mathrm{~min}$. at $1100 \mathrm{rpm}$. The processed powder was dried and then pressed into disks. The disks were sintered at $T_{\mathrm{S}}=1200-1300^{\circ} \mathrm{C}$ for $5 \mathrm{~h}$. The crystal structure of the

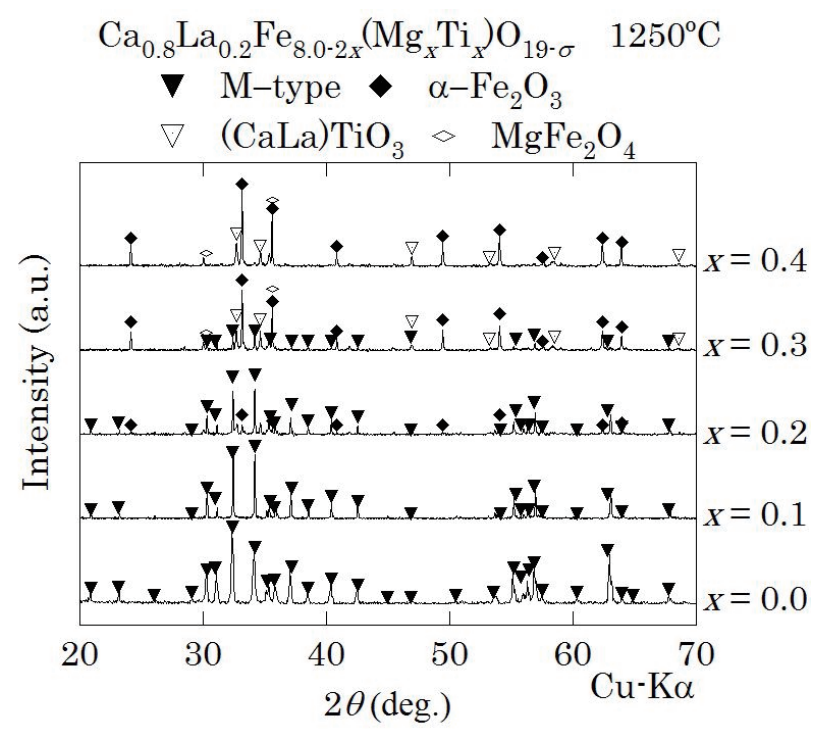

Fig. 1 X-ray diffraction patterns of $\mathrm{Ca} 0.8 \mathrm{La}_{0 .} \mathrm{Fe}_{.0-2 \times} \mathrm{Mg}_{x} \mathrm{Ti}_{x} \mathrm{O}_{19-\sigma}(x=0.0-0.4)$ sintered at $1250^{\circ} \mathrm{C}$. 
sample was examined by powder X-ray diffraction (XRD) analysis with $\mathrm{Cu}-\mathrm{Ka}$ radiation. The magnetization was measured with a vibrating sample magnetometer (Tamakawa TM-VSM2130HGC) and a superconducting quantum interference device (SQUID) magnetometer (Quantum Design MPMS-XL). The composition was analyzed by the use of an Energy Dispersive X-ray spectrometry (EDX). Here, the composition of oxygen was not examined because the analyses of light elements are less accurate than those of heavy elements.

\section{Results and discussion 3-1 Mg-Ti substituted Ca-based M-type ferrite} Figure 1 shows the X-ray diffraction patterns of

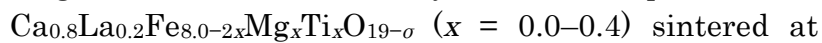
$1250^{\circ} \mathrm{C}$. The main phase is M-type ferrite for the samples with $x \leq 0.2$. The sample at $x=0.2$ also showed the minority $\alpha-\mathrm{Fe}_{2} \mathrm{O}_{3}$ phase. The sample at $x=0.3$ was made up of the mixed phases of $\alpha-\mathrm{Fe}_{2} \mathrm{O}_{3}$, M-type ferrite, $\mathrm{MgFe}_{2} \mathrm{O}_{4}$, and (CaLa)TiO3. The samples at $x \geq 0.4$ consisted of $\alpha-\mathrm{Fe}_{2} \mathrm{O}_{3}, \mathrm{MgFe}_{2} \mathrm{O}_{4}$, and (CaLa) $\mathrm{TiO}_{3}$ phases, but didn't contain M-type ferrite phase. The chemical composition of the perovskite compound of $(\mathrm{CaLa}) \mathrm{TiO}_{3}$ can be various forms such as $\mathrm{Ca}_{0.2} \mathrm{La}_{0.53} \mathrm{TiO}_{3}$, $\mathrm{Ca}_{0.4} \mathrm{La}_{0.4} \mathrm{TiO}_{3}$, and $\left.\mathrm{Ca}_{0.12} \mathrm{La}_{0.58} \mathrm{TiO}_{3} .{ }^{15},{ }_{16}\right)$ It is difficult to determine the chemical composition exactly because the lattice constant of $(\mathrm{CaLa}) \mathrm{TiO}_{3}$ is similar to that of $\mathrm{CaTiO}_{3}$. Since $\mathrm{Ca}$ and $\mathrm{La}$ cations became starting materials to form the perovskite compounds, M-type ferrite was not formed.

Figure 2 shows the room-temperature saturation magnetization of $\mathrm{Ca} .{ }_{8} \mathrm{La}_{0.2} \mathrm{Fe}{ }_{8.0-2 x} \mathrm{Mg}_{x} \mathrm{Ti}_{x} \mathrm{O}_{19-\sigma} \quad(x=$ $0.0-0.4)$ sintered at $1200-1300^{\circ} \mathrm{C}$. Here, the saturation magnetization of the sample at $x=0.0$ is that of sample prepared with the optimum preparation conditions in the previous study. ${ }^{11}$ ) The saturation magnetization decreased with increasing the amount of $\mathrm{Mg}$-Ti substitution. The gradual decrease of the magnetization indicated the formation of $\mathrm{Mg}$-Ti substituted M-type ferrite at $x=0.1$ and $1225^{\circ} \mathrm{C} \leq T_{\mathrm{S}} \leq 1250^{\circ} \mathrm{C}$. The substitution of non-magnetic $\mathrm{Mg}^{2+}$ and $\mathrm{Ti}^{4+}$ for magnetic $\mathrm{Fe}^{3+}$ can decrease total magnetic moment. Even at the same substitution rate of $x=0.1$, however, the samples with $T_{\mathrm{S}}=1200^{\circ} \mathrm{C}$ and $1300^{\circ} \mathrm{C}$ showed low magnetizations. The decrease of the magnetization was more obvious at $x=0.2$ and $T_{\mathrm{S}} \geq 1225^{\circ} \mathrm{C}$ in spite that the main phase was the M-type phase. It should be noted that the synthesis condition of Ca-based M-type ferrite is so delicate that the M-type structure can easily be broken. ${ }^{11)}$ Since the sample at $x=0.2$ and $T_{\mathrm{S}}=1200^{\circ} \mathrm{C}$ didn't contain M-type ferrite phase, the saturation magnetization became much smaller than those of the $x=0.2$ samples with higher sintering temperatures.

Figure 3 shows the temperature dependence of magnetization of $\mathrm{Ca}_{0.8} \mathrm{La}_{0.2} \mathrm{Fe}_{8.0-2 \times} \mathrm{Mg}_{x} \mathrm{Ti}_{x} \mathrm{O}_{19-\sigma}$ at $0.0 \leq x$ $\leq 0.2$. The Curie temperature decreased with increasing the amount of $\mathrm{Mg}$-Ti substitution. The non-magnetic

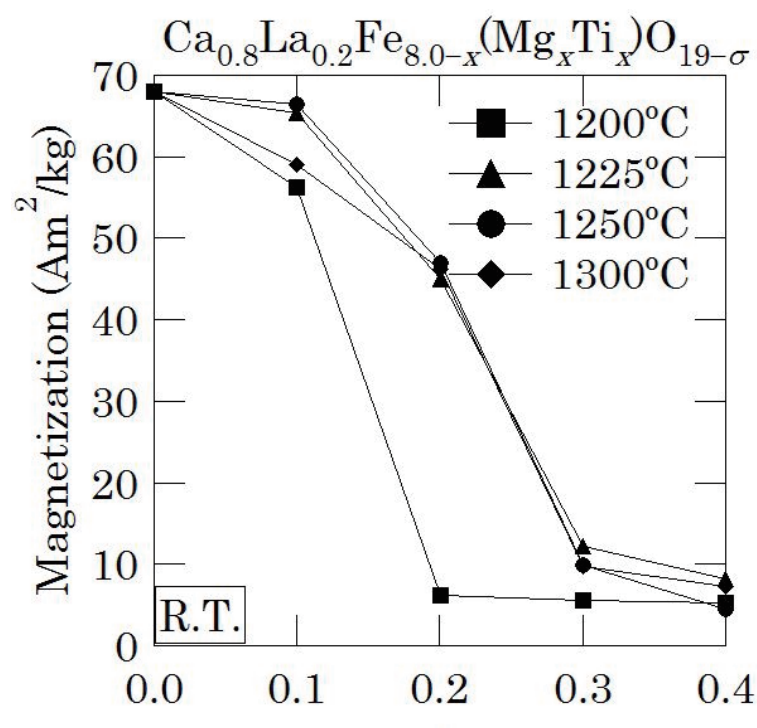

Fig. 2 Saturation magnetization at room temperature of $\mathrm{Ca}_{0.8} \mathrm{La}_{0.2} \mathrm{Fe}_{8.0-2 x} \mathrm{Mg}_{x} \mathrm{Ti}_{x} \mathrm{O}_{19-\sigma} \quad(x=$ $0.0-0.4)$ sintered at $1200,1225,1250^{\circ} \mathrm{C}$ and $1300^{\circ} \mathrm{C}$.

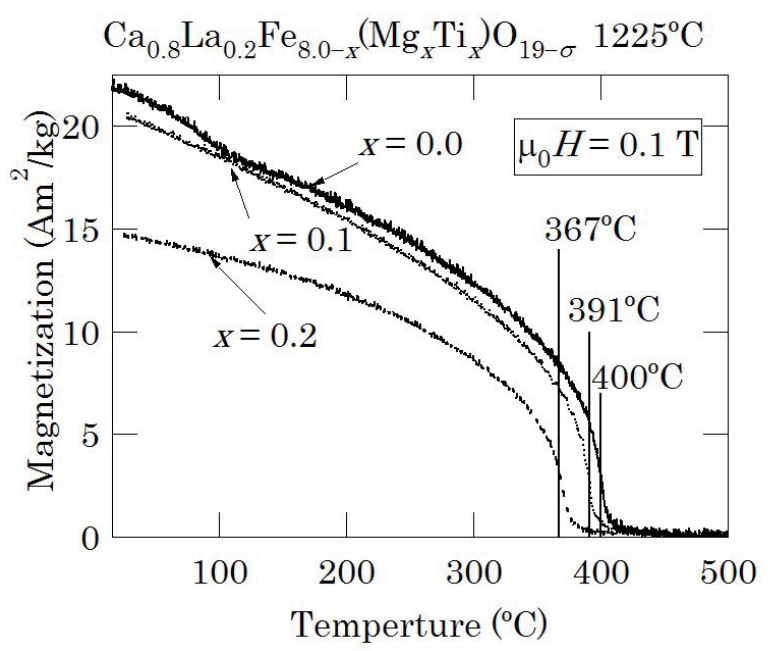

Fig. 3 Temperature dependence of magnetization of $\mathrm{Ca}_{0.8} \mathrm{La}_{0.2} \mathrm{Fe}_{8.0-2 x} \mathrm{Mg}_{x} \mathrm{Ti}_{x} \mathrm{O}_{19-\sigma} \quad(x=0.1$ and 0.2$)$ sintered at $1225^{\circ} \mathrm{C}$ and $x=0.0$ sintered at $1250^{\circ} \mathrm{C}$.

$\mathrm{Mg}^{2+}$ and $\mathrm{Ti}^{4+}$ ions decrease the number of the connection between magnetic iron ions $\left(\mathrm{Fe}^{3+}-\mathrm{O}^{2-}-\mathrm{Fe}^{3+}\right)$ in $\mathrm{Mg}$-Ti substituted Ca-based M-type ferrite at $x \leq 0.2$.

\section{3-2 Al substituted Ca-based M-type ferrite}

Figure 4 shows X-ray diffraction patterns of $\mathrm{Ca}_{0.8} \mathrm{La}_{0.2} \mathrm{Fe}_{8.0-} \mathrm{Al}_{x} \mathrm{O}_{19-\sigma}(x=1.0-4.0)$ sintered at $1250^{\circ} \mathrm{C}$. The main phase is $\mathrm{M}$-type ferrite for these samples although minority phases of $\mathrm{CaFe}_{4} \mathrm{O}_{7}$ and $\mathrm{CaAl}_{4} \mathrm{O}_{7}$ are also observed. The formation of $\mathrm{CaFe}_{4} \mathrm{O}_{7}$ can be caused by the deficiency of $\mathrm{Fe}$ cations to form the M-type structure. Therefore, we attempted to increase the amounts of $(\mathrm{Fe}+\mathrm{Al}) /(\mathrm{Ca}+\mathrm{La})$ to 10.

Figure 5 shows X-ray diffraction patterns of 
$\mathrm{Ca}_{0.8} \mathrm{La}_{0.2} \mathrm{Fe}_{10-} \mathrm{Al}_{x} \mathrm{O}_{19-\sigma}(x=1.0-4.0)$ sintered at $1300^{\circ} \mathrm{C}$. The samples of $x=1.0$ and 2.0 are in the single phase of M-type ferrite, but the samples of $x=3.0$ and 4.0 have the main M-type ferrite phase and the minority $\mathrm{CaFe}_{4} \mathrm{O}_{7}$ phase. Here, it should be noted that high temperature sintering is necessary for formation of

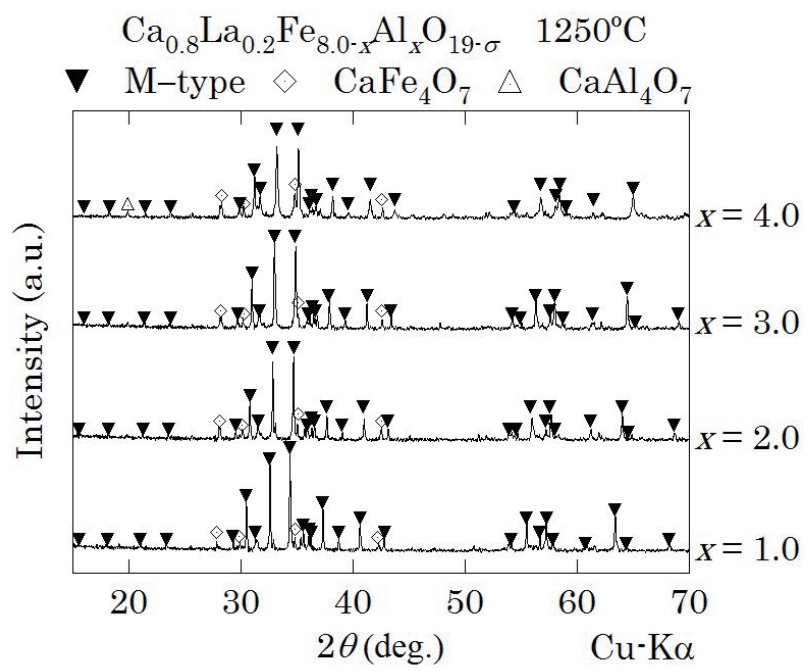

Fig. 4 X-ray diffraction patterns of $\mathrm{Ca}_{0.8} \mathrm{La}_{0.2} \mathrm{Fe}_{8.0-} \mathrm{Al}_{x} \mathrm{O}_{19-\sigma}(x=1.0-4.0)$ sintered at $1250^{\circ} \mathrm{C}$

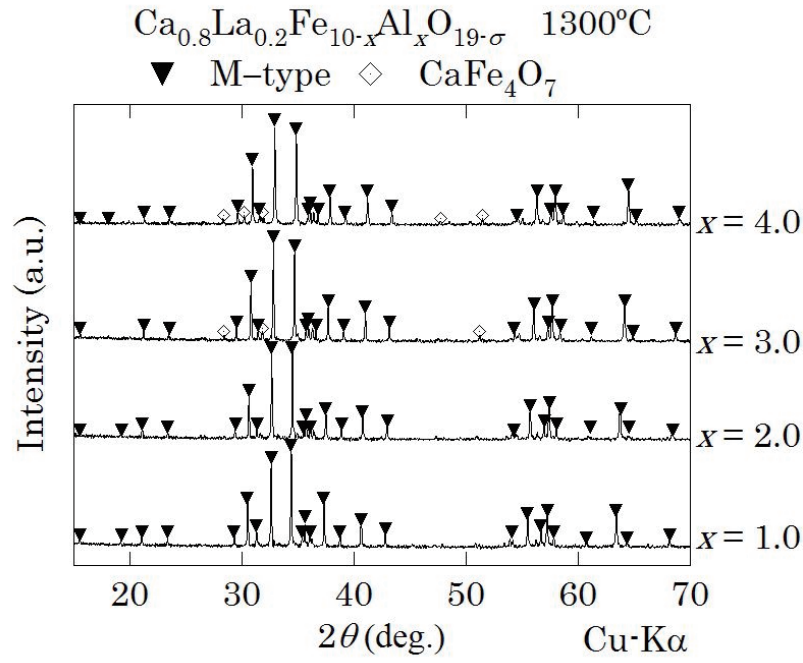

Fig. 5 X-ray diffraction patterns of Ca0.8La0.2 $\mathrm{Fe}_{10-x} \mathrm{Al}_{x} \mathrm{O}_{19-\sigma}(x=1.0-4.0)$ sintered at $1300^{\circ} \mathrm{C}$.

Table 1 Ionic radii of each coordination number of $\mathrm{Fe}$ and $\mathrm{Al}$.

\begin{tabular}{|c|c|c|c}
\hline & Octahedral & Tetrahedral & $\begin{array}{c}\text { Trigonal } \\
\text { bipyramidal }\end{array}$ \\
\hline $\mathrm{Fe}^{3+}(\AA)$ & 0.645 & 0.49 & 0.58 \\
\hline $\mathrm{Al}^{3+}(\AA)$ & 0.535 & 0.39 & 0.48 \\
\hline
\end{tabular}

$\mathrm{CaAl}_{12} \mathrm{O}_{19}{ }^{17}$ ) Actually, Nagumo et al. reported that iron-substituted hibonite $\left(\mathrm{CaAl}_{12-x} \mathrm{Fe}_{x} \mathrm{O}_{19}\right)$ samples were synthesized at a relatively low sintering temperature of $1300^{\circ} \mathrm{C}$ as the amount of $\mathrm{Al}$ was decreased. ${ }^{18)}$ Therefore, it is possible that the substitution of $\mathrm{Al}$ may increase the suitable sintering temperature to form the single M-type phase. Also, the diffraction peaks of M-type phase shifted to the higher angle side as the substitution amount increased. Table 1 shows the ionic radii of $\mathrm{Fe}^{3+}$ and $\mathrm{Al}^{3+}$.19) Since $\mathrm{Al}^{3+}$ is smaller than $\mathrm{Fe}^{3+}$, the lattice constants decrease with increasing the amount of $\mathrm{Al}^{3+}$, as shown in Fig. 6. Therefore, the Al-substituted M-type ferrite was formed successfully.

Figure 7 shows the saturation magnetization and the coercivity at room temperature of

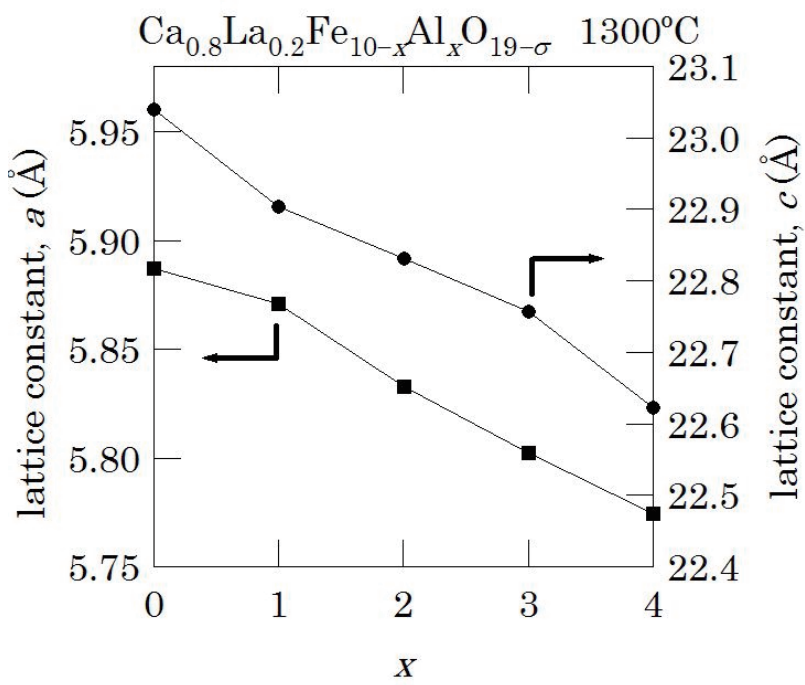

Fig. 6 Lattice constant of $\mathrm{Ca}_{0.8} \mathrm{La}_{0.2} \mathrm{Fe}_{10-} \mathrm{Al}_{x} \mathrm{O}_{19-\sigma}(x$ $=1.0-4.0)$ sintered at $1300^{\circ} \mathrm{C}$.

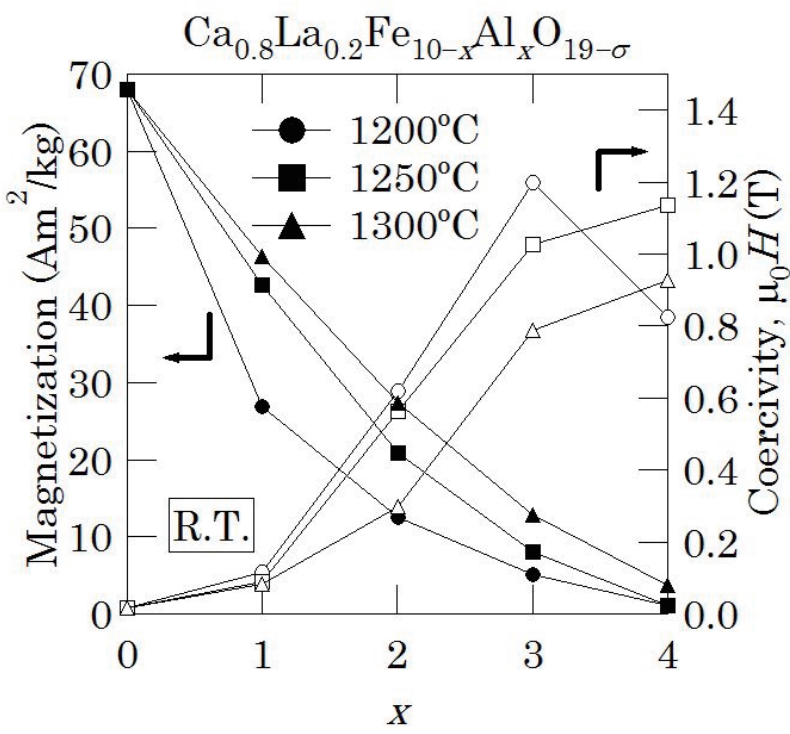

Fig. 7 Saturation magnetization and coercivity at room temperature of $\mathrm{Ca}_{0.8} \mathrm{La}_{0.2} \mathrm{Fe}_{10-x} \mathrm{Al}_{x} \mathrm{O}_{19-\sigma}(x=$ $1.0-4.0)$ sintered at $1200-1300^{\circ} \mathrm{C}$. 
$\mathrm{Ca}_{0.8} \mathrm{La}_{0.2} \mathrm{Fe}_{10-} \mathrm{Al}_{x} \mathrm{O}_{19-\sigma} \quad(x=1.0-4.0)$ sintered at $1200-1300^{\circ} \mathrm{C}$. The saturation magnetization decreased and the coercivity increased with increasing amount of Al. The decrease of the saturation magnetization at room temperature is caused by the substitution of non-magnetic ions $\left(\mathrm{Al}^{3+}\right)$ for magnetic ions $\left(\mathrm{Fe}^{3+}\right)$, which can decrease the intrinsic magnetic moment and the Curie temperature.

In contrast, the $\mathrm{Al}$ substitution increased the coercivity of the Ca-based M-type ferrite although the coercivity of the starting sample without $\mathrm{Al}$ was small. ${ }^{11)}$ The Al-substitution effect on coercivity is similar to those of other M-type ferrites. For instance, Haneda and Kojima reported that $\mathrm{BaAl}_{x} \mathrm{Fe}_{12-} \mathrm{O}_{19}$ exhibited a large increase in coercivity and that the magnetocrystalline anisotropy field contributed greatly to the increase of coercivity. ${ }^{20}$ ) De Bitetto also found that the anisotropy field of $\mathrm{SrO} \cdot \mathrm{xAl}_{2} \mathrm{O}_{3} \cdot(6-x) \mathrm{Fe}_{2} \mathrm{O}_{3}$ increased as the substitution amount of $\mathrm{Al}(\mathrm{x})$ was increased. ${ }^{21)}$

The Al-substitution effects on coercivity of M-type ferrites have been attributed to the variation of magnetocrystalline anisotropy under the assumption of a single-domain model (Stoner-Wohlfarth model).8,10,20-21) This assumption is plausible because the single-domain structure can be stabilized by the reduction of magnetostatic energy if the decrease of the saturation magnetization is more significant than the change of the magnetocrystalline anisotropy. ${ }^{22-23)}$ According to the Stoner-Wohlfarth model, the coercivity can be expressed as

\section{$H_{\mathrm{C}} \propto K_{1} / M_{\mathrm{S}}$}

where $H_{\mathrm{C}}$ is the coercivity, $K_{1}$ is the magnetocrystalline uniaxial anisotropy constant, and $M_{\mathrm{S}}$ is the saturation magnetization. If the decrease of $K_{1}$ is smaller than the decrease of $M_{\mathrm{S}}, H_{\mathrm{C}}$ can be increased. The studies of $\mathrm{Al}$ substituted Sr-based M-type ferrite also showed that the saturation magnetization decreased and the coercivity increased with increasing amount of Al. ${ }^{8-10,21)}$ This tendency is consistent with our result.

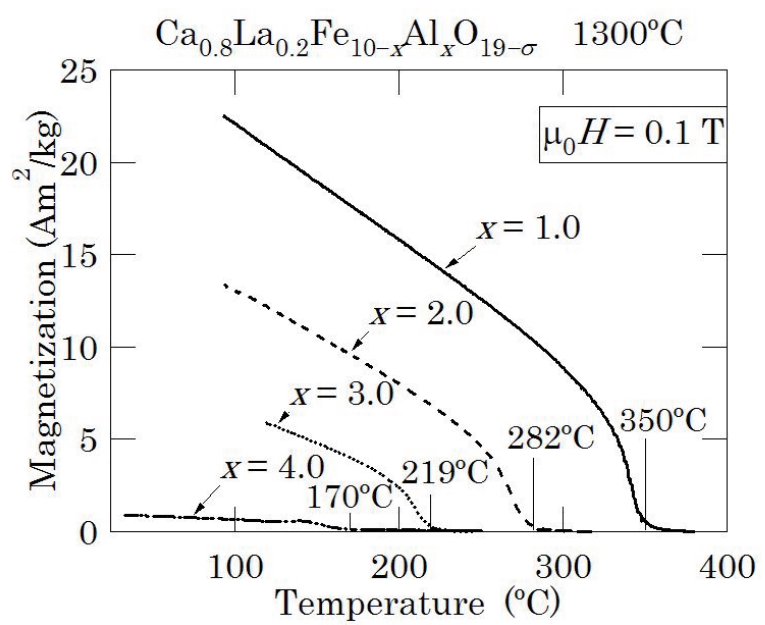

Fig. 8 Temperature dependence of magnetization of Ca0.8La0.2 $\mathrm{Fe}_{10-x} \mathrm{Al}_{x} \mathrm{O}_{19-\sigma}(x=1.0-4.0)$ sintered at $1300^{\circ} \mathrm{C}$.
Figure 8 shows the temperature dependence of magnetization of $\mathrm{Ca}_{0.8} \mathrm{La}_{0.2} \mathrm{Fe}_{10-x} \mathrm{Al}_{x} \mathrm{O}_{19-\sigma}(x=1.0-4.0)$ sintered at $1300^{\circ} \mathrm{C}$. The Curie temperature of these samples decreased with increasing the amount of Al. As the $\mathrm{Al}$ substitution increased by $\Delta x=1$, the Curie temperature decreased by $\Delta T_{\mathrm{C}}=50-70^{\circ} \mathrm{C}$. The substitution of the non-magnetic $\mathrm{Al}^{3+}$ for $\mathrm{Fe}^{3+}$ causes to decrease the links of $\mathrm{Fe}^{3+}-\mathrm{O}^{2-}-\mathrm{Fe}^{3+}$, and consequently weakens the superexchange interaction in the M-type structure.

Figure 9 shows the magnetization curves at $5 \mathrm{~K}$ $\left(-268^{\circ} \mathrm{C}\right)$ of $\mathrm{Ca}_{0.8} \mathrm{La}_{0.2} \mathrm{Fe}_{10-} \mathrm{Al}_{x} \mathrm{O}_{19-\sigma}(x=1.0$ and 2.0$)$ sintered at $1300^{\circ} \mathrm{C}$. The saturation magnetic moment per molecule at $x=1.0$ is estimated to be $12.5 \mu \mathrm{B} / \mathrm{f}$.u. from the magnetization at $\mu_{0} \mathrm{H}=7 \mathrm{~T}\left(85.0 \mathrm{Am}^{2} / \mathrm{kg}\right)$. The EDX analysis showed the chemical formula of this sample as $\mathrm{Ca}_{0.88} \mathrm{La}_{0.12} \mathrm{Fe}_{8.80} \mathrm{Al}_{1.01} \mathrm{O}_{15.8}$. Here, the composition ratio of oxygen is estimated from the charge balance with the concentration of $\mathrm{Ca}^{2+}, \mathrm{La}^{3+}, \mathrm{Fe}^{3+}$, and $\mathrm{Al}^{3+}$ cations.

The saturation magnetic moment per molecule at $x=$ 2.0 is also estimated to be $7.86 \mu \mathrm{B} / \mathrm{f}$.u. from the magnetization at $\mu_{0} H=7 \mathrm{~T}\left(55.1 \mathrm{Am}^{2} / \mathrm{kg}\right)$. The EDX analysis of this sample showed the chemical formula of $\mathrm{Ca}_{0.83} \mathrm{La}_{0.17} \mathrm{Fe}_{7.88} \mathrm{Al}_{1.83} \mathrm{O}_{15.7}$.

Comparing these two results, the difference of the magnetic moment between these two samples is $4.7 \mu \mathrm{B}$, which is approximately close to the magnetic moment of $\mathrm{Fe}^{3+}\left(5 \mu_{\mathrm{B}}\right)$. In other words, as the substitution amount of $\mathrm{Al}^{3+}$ increased by 1 , one $\mathrm{Fe}^{3+}$ located at the up spin sites decreased. In other words, $\mathrm{Al}^{3+}$ prefers to be located at the up spin sites. Therefore, the saturation magnetization was greatly decreased even by the small amount of $\mathrm{Al}$ substitution.

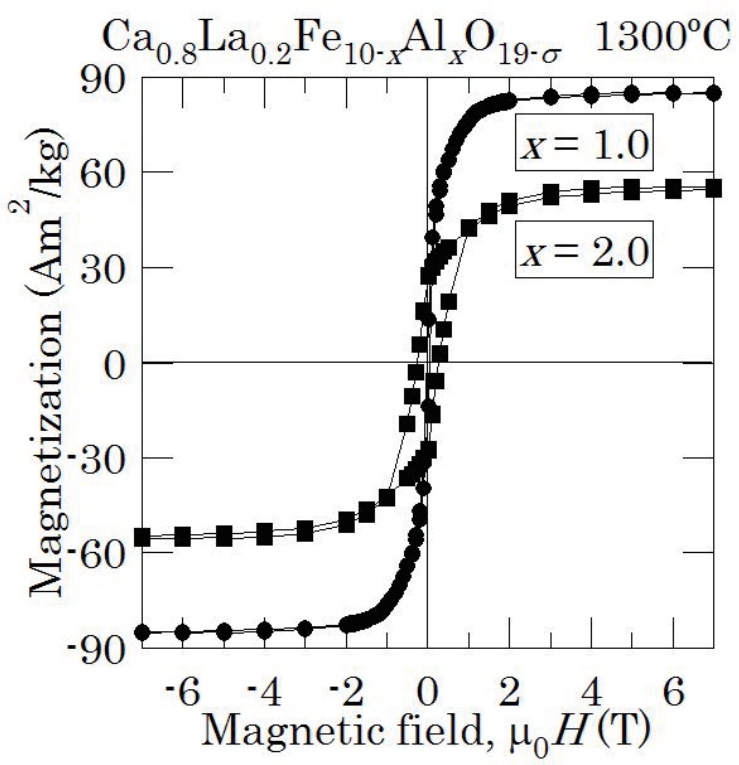

Fig. 9 Magnetization curves at $5 \mathrm{~K}\left(-268^{\circ} \mathrm{C}\right)$ of $\mathrm{Ca}_{0.8} \mathrm{La}_{0.2} \mathrm{Fe}_{10-} \mathrm{Al}_{x} \mathrm{O}_{19-\sigma}(x=1.0$ and 2.0) sintered at $1300^{\circ} \mathrm{C}$. 


\section{Conclusion}

We have investigated the synthesis conditions and magnetic properties of non-magnetic-ion-substituted Ca-based M-type ferrites. In the $\mathrm{Mg}$-Ti substitution case of $\mathrm{Ca}_{0.8} \mathrm{La}_{0.2} \mathrm{Fe}_{8.0-2 \times} \mathrm{Mg}_{X} \mathrm{Ti}_{x} \mathrm{O}_{19-\sigma}$, the single-phase sample was formed at $x=0.1$. As the amount of substitution increased, both the saturation magnetization and the Curie temperature decreased. In the $\mathrm{Al}$ substitution case of $\mathrm{Ca}_{0.8} \mathrm{La}_{0.2} \mathrm{Fe}_{y-x} \mathrm{Al}_{x} \mathrm{O}_{19-\sigma}$, samples, the single M-type phase samples were formed at $x=1.0$ and 2.0 sintered at $1300^{\circ} \mathrm{C}$. As the amount of substituted $\mathrm{Al}$ increased, the saturation magnetization and the Curie temperature decreased and the coercivity increased. The Al substitution seems to change the distribution of iron cations in the M-type structure and to cause to change the magnetic properties.

\section{References}

1) J. Smit and H. P. J. Wijn: Ferrites, pp. 182-184, pp. 193-194 (Philips Technical Library, Netherlands 1959).

2) S. Chikazumi: Physics of Ferromagnetism, p. 212 (Oxford University Press, Oxford, 2009).

3) G. W. Rathenau: Rev. Mod. Phys., 25, 297 (1953).

4) Ü. Özgür, Y. Alivov, and H. Morkoc: J. Mater. Sci-Mater. El., 20, 789 (2009).

5) S. Alablance, J. Thery, and D. Viven: Mater. Res. Bull., 24, 475 (1989)

6) V. V. Soman, V. M. Nanoti, and D. K. Kulkarni: Ceram. Int., 39, 5713 (2013).

7) V. V. Soman, V. M. Nanoti, D. K. Kulkarni, and V. V. Soman: Physics Procedia, 54, 30 (2014).

8) M. Liu, X. Shen, F. Song, J. Xiang, and X. Meng: J. Solid State Chem., 184, 871 (2011).
9) H. Z. Wang, B. Yao, Y. Xu, Q. He, G. H. Wen, S. W. Long, J. Fan, G. D. Li, L. Shan, B. Liu, L. N. Jiang, and L. L. Gao: J. Alloy. Compd., 537, 43 (2012).

10) H. Luo, B. K. Rai, S. R. Mishra, V. V. Nguyen, J. P. Liu: J. Magn. Magn. Mater., 324, 2602 (2012).

11) M. Shigemura, K. Watanabe, K. Kakizaki, and K. Kamishima: J. Magn. Soc. Jpn, 41, 10 (2017).

12) T. Shimizu, M. Matsui: Sci. Technol. Adv. Mater., 4, 469 (2003).

13) T. Shimizu, H. Asano, M. Matsui: J. Magn. Magn. Mater., 310, 1835 (2007).

14) F. W. Clarke and H. S. Washington: The Composition of the Earth's Crust, pp. 20-21 (United States Geological Survey, Washington, 1924).

15) Z. Zhang, G. R. Lumpkin, C. J. Howard, K. S. Knight, K. R. Whittle, and K. Osaki: J. Solid State Chem., 180, 1083 (2007).

16) The Powder Diffraction File (PDF00-055-0922) by the Internal Center for Diffraction Data (ICDD): L. Vasylechko, Semiconductor Electronic Dept., L`viv Polytechic Natinal Univ., Ukraine. ICDD Grant-in-Aid, (2016).

17) H. H. Mao, M. Selleby, and B. Sundman: CALPHAD, 28 [3], 307 (2004).

18) H. Nagumo, K. Watanabe, K. Kakizaki, and K. Kamishima: J. Magn. Soc. Jpn, 41, 20 (2017).

19) R. D. Shannon: Acta Cryst. , A32, 751 (1976).

20) K. Haneda and H. Kojima: Jpn. J. Appl. Phys., 12, 355 (1973).

21) D. J. De Bitetto: J. Appl. Phys., 35, 3482 (1964).

22) Ibid. 1, p. 68.

23) Ibid. 2, p. 455.

Received Apr. 19, 2017; Accepted Jul. 7, 2017 